\section{Genvariant med} lavere risiko \section{for koronarsykdom}

En genvariant som er assosiert med lavere risiko for iskemisk hjertesykdom, er påvist i en studie basert på genomene til flere tusen islendinger.

I en studie utgått fra firmaet deCODE Genetics-Amgen og forskningsmiljøer på Island ble genomene til 2636 islendinger sekvensert (1). Påviste genvarianter ble så imputert i genomet til rundt 400000 islendinger. Sammenhengen mellom genvariant og kolesterolnivå ble undersøkt og deretter testet for replikasjon $\mathrm{i}$ andre europeiske populasjoner.

Det ble funnet en sammenheng mellom en variant av $A S G R 1$ og lavere kolestrolnivå. $A S G R 1$ koder for en reseptor som er involvert i homeostasen av sirkulerende glykoproteiner. De som hadde denne genvarianten, hadde $34 \%$ lavere risiko for iskemisk hjertesykdom (95\% KI 21-45).

- I denne studien er det brukt ny og moderne sekvenseringsteknologi, sier professor Ole A. Andreassen ved Oslo universitetssykehus og Universitetet i Oslo. - Med denne metoden kan man bestemme alle genvariantene i det menneskelige genom, men dette er fremdeles svært kostbart. Derfor sekvenserte forskerne genomet til ca. 2600 personer med påfølgende imputasjon i flere hundre tusen for å få tilstrekkelig statistisk styrke til å oppdage sammenhengen mellom sjeldne genvarianter og kolesterolnivået, forklarer han.

- Imputasjon innebærer at man estimerer genvarianter som ikke er genotypet, gjennom statistiske analyser basert på genetiske varianter på hver side av den aktuelle genvarianten. Det ble identifisert en tap-av-funksjonmutasjon, dvs.at proteinet genet koder for, mister funksjon. Dette er et såkalt naturlig eksperiment, der man via en spesifikk genetisk variant kan avdekke viktige mekanismer for sykdom hos mennesker. Slike funn vil kunne brukes som utgangspunkt for å utvikle nye legemidler og illustrerer potensialet til «persontilpasset medisin», sier Andreassen.

\section{Martine Rostadmo}

Tidsskriftet

\section{Litteratur}

1. Nioi P, Sigurdsson A, Thorleifsson $G$ et al. Variant ASGR1 associated with a reduced risk of coronary artery disease. N Engl J Med 2016; 374: 2131-41.

\title{
Urbefolkninger har dårligere helse
}

\author{
En stor studie viser at urbefolkninger over hele verden kommer mye \\ dårligere ut enn andre på flere mål på helse.
}

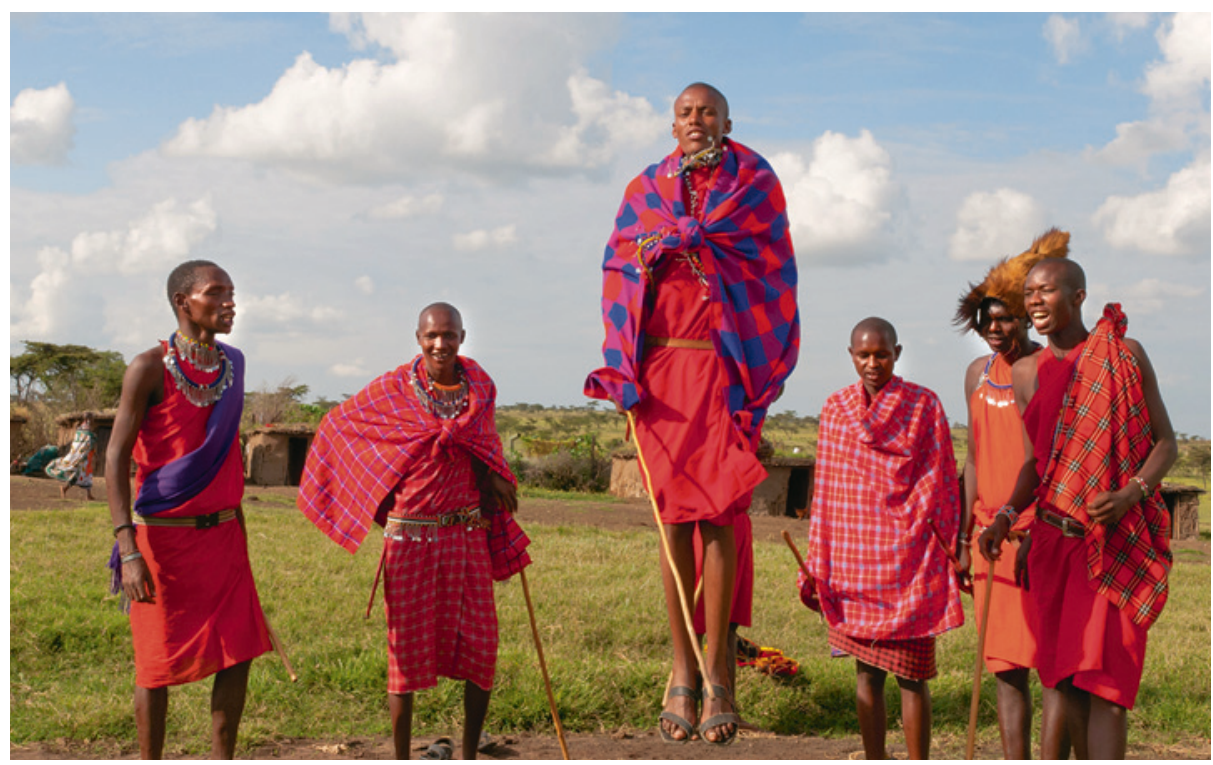

Masaier gjør sin tradisjonelle dans for turistene. Masai Mara nasjonalpark, Kenya. Foto: Bill Bachmann/AGE/ Scanpix

Helseforskjeller mellom flere urbefolkninger og befolkningen ellers i 23 land er nylig unders $ø \mathrm{kt} \mathrm{i}$ en stor studie som nettopp er publisert i tidsskriftet The Lancet (1). Studien er basert på data fra 28 ulike urbefolkninger med til sammen rundt 154 millioner mennesker for perioden 1997-2014. Dette tilsvarer om lag halvparten av verdens totale urbefolkning. Med unntak av inuittene på Grønland var alle urbefolkningene minoriteter i landene de lever i.

Forventet levealder var signifikant lavere enn $\mathrm{i}$ den øvrige befolkningen i 15 av de 18 urbefolkningene der det fantes data for dette. Størst forskjell var det for bakafolket i Kamerun og masaifolket i Kenya, med henholdsvis $21,5 \%$ og $10 \%$ lavere forventet levealder enn i befolkningen ellers. I høyinntektslandene Canada og Australia ble det også funnet store forskjeller, med $12,5 \%$ og $10 \%$ lavere forventet levealder blant urbefolkningene.

Spedbarnsdødeligheten var også høyere blant urbefolkningene, bortsett fra i Sverige, Chile og på Hawaii. For mødredødeligheten ble tallene i mange land for små til at man kunne gjøre pålitelige beregninger, men den var signifikant høyere blant urbefolkningene i
Australia, Colombia, New Zealand og Panama. I Panama var risikoen for å dø i forbindelse med svangerskap eller fødsel over seks ganger så stor blant urbefolkningskvinner som blant andre kvinner i landet. Det ble også funnet betydelig høyere forekomst av underernæring blant barn, fedme blant barn og fedme blant voksne i omtrent halvparten av befolkningsgruppene som inngikk i studien.

Forskerne bak studien mener at det er et stort behov for målrettede tiltak for å bedre helsen blant verdens urbefolkninger. De uttrykker også bekymring over at Norge, Sverige og Danmark har lovforbud mot innsamling av data basert på etnisitet, noe som vanskeliggjør arbeidet med å avdekke forskjeller.

\section{Matilde Risopatron Berg}

Holter legekontor

\section{Litteratur}

1. Anderson I, Robson B, Connolly M et al. Indigenous and tribal peoples' health (The LancetLowitja Institute Global Collaboration): a population study. Lancet 2016. E-publisert 20.4.2016. 